Arab Univ. J. Agric. Sci., Ain Shams Univ., Cairo, Egypt

28(4), 1065-1076, 2020

Website: http://ajs.journals.ekb.eg

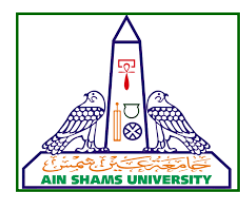

1065

\title{
Portable Solar-Energy Drying System with Mechanical Stirring Device for Cereals under Egyptian Conditions
}

\author{
Ahmed M El-Sheikha ${ }^{1}$, Rashad A Hegazy ${ }^{\star}$ \\ 1- Agric. Engineering Dept, Fac of Agric, Damietta Univ, Damietta, P.O. Box. 34517, Egypt \\ 2- Agric. Engineering Dept, Fac of Agric, Kafrelsheikh Univ, Kafrelsheikh, P.O. Box. 33516, Egypt \\ *Corresponding author: rashad.hegazy@agr.kfs.edu.eg
}

Received 19 September, 2020

Accepted 21 October, 2020

\begin{abstract}
The main goal of this present study is utilizing the available solar energy to dry main cereals under Egyptian conditions using a portable drying system (PDS) with mechanical stirring. The developed multi-commodity portable drying system has a dimensions of $5.5 \times 2 \times 2.8 \mathrm{~m}$ (length, width and height, respectively), and the height is $2.8 \mathrm{~m}$. The dimension of air heating room was $2.4 \times 2.4 \times 1.3 \mathrm{~m}$ (length $\mathrm{x}$ width $\mathrm{x}$ height, respectively). A transparent $4 \mathrm{~mm}$ polycarbonate sheet used to cover both drying chamber and heating room. A movable transitionally stirring system powered by electric motor was attached to the dryer and it consisted of a stirring arms made from a rectangular plates of stainless steel that had $1900 \mathrm{~mm}$ long $20 \mathrm{~mm}$ thickness and $70 \mathrm{~mm}$ height and fixed in the steering shaft that moves by chains at both ends. The power which required for stirring and rotational moving have been calculated and analyzed their arms motion to define the suitable horsepower motor to be used. Three solar modules (300 W each) as solar panels was used to produce 900 watts was used to produce 900 watts (with considering the solar panel efficiency) go run the electric motor. The drying time and drying temperature were employed as a scientific base to compare between the dryer development and the open-air sun drying. The harvested rice grain was used in $30 \mathrm{~mm}$ thick of layers in both dryers. The overall area used to install the dryer was $14 \times 6 \mathrm{~m}$. The new drying system was evaluated based on the drying time to achieve the target crop moisture content for storage and the difference in crop layers during the drying process. Also, rice milling was conducted after drying to record the milling indicators
\end{abstract}

for both the PDS an open air solar drying. The average difference in temperature was $0.16^{\circ} \mathrm{C}$ for the PDS, while it was $2.77^{\circ} \mathrm{C}$ for the open-air sun drying for two different measuring time, 10 am and $2 \mathrm{pm}$. The less differences in layers' temperature are due to the stirring operation that is undertaken mechanically and on the desired base. The PDS takes less time than conventional sun drying to dry the rice grains as the rice grains reached to $12 \% \mathrm{MC}$ after 10 hours of drying process. PDS gave better milling quality in term of head rice than the traditional open air solar drying method.

Keywords: Solar drying, Stirring system, Rice grains, Passive dryer, Portable drying

\section{Introduction}

Renewable energy is commonly used now in drying as alternative resource to traditional ones, which led to cost reduction and mitigate the environmental problems. Thus, moving to the utilization of clean energy such as solar and thermal power in food production and industries has been done and is being conducted in many ways (Eswara and Ramakrishnarao 2013). Researchers can use some indicators such as energy consumed by the process during the production, time to power payback, carbon dioxide emission when they use the solar dryers' concept for drying (Eltawil et al 2018). Piacentini and Mujumdar (2009) recommended that using the electricity in air drying systems, where the experiments cleared that about 15 tons/year of carbon dioxide can be eliminated with using $100 \mathrm{kWh} /$ day as electrical energy for 25 days/month for 11 months/year. Ekechukwu and Norton (1999) stated that using solar dryers can reduce greenhouses gas 
(GHG) emission more than using other traditional drying methods. For better planning to use solarbased dryers, a detailed studies and design concepts need to run for assisting the economic viability and investment in similar systems. The technical visibility should be clear enough and to consider the different side of operating parameters with associated costs. It was clear that designing and using the solar dryers is a capital intensive method compared with other commercial dryers (Tiwari, 2016). Aravindh et al (2014) gave huge attention to correctly validate the economic use and operation of solar dryers, they cleared that can study the life cycle saving, investment return, fixed and variable annual costs. However, most calculations of drying process are mainly depended on critical factors as the physical properties of drying crops, weather conditions, and the design factors such as type, size, and working characteristics (Kumar et al 2016, Purohit et al 2006). From socio-economic prospective, and the type of technology, renewable energy including the thermal and solar energy provided most of the jobs. Where, 9.8 million persons got involved and had opportunity to work in this sector in 2016. Most of these jobs opportunities located in Asia, where, China alone dominated $62 \%$ of all the renewable energy jobs (Renewable Energy Policy REN21 2017). Moreover, utilizing solar energy significantly elevated risks of non-allergic respiratory, cancer, allergic diseases, and adverse outcomes in pregnancy and birth enhancement which led to overall public health improvement by reducing GHG emissions (WHO 2005).

Both, sun heat and the exiting wind in a specific location can affect solar drying specially the open sun drying type. The color of crop surface is a major reason to determine the amounted absorbed of any residual part of solar energy. Increasing crop temperature and crop heat gained results in wavelength radiation loss with help in crop drying with the help of convection loss and mass transfer from the surface of the crop to surrounding air through moist air. The role of forcing air moving by air speed is very important in the progress of drying as evaporation and convective heat loss will increase. The concept of drying is creating evaporative losses due to reduced moisture which led to smooth drying process (Tiwari et al 2016). The traditional methods using open sun drying, there is uncontrolled variables where everything is depends on the nature. Moisture content, temperature variation, required heat, and air flow rate in drying variable characteristics and not fixed every time everywhere and not necessarily to be the same as previous days or previous experiments (Kumar et al 2016). Salvatierra-Rojas et al (2017) conducted the several experiments to test solar dryer that was classified as inflatable solar dryer. The dryer design and idea was concluded from the solar tunnel dryer developed in Hohenheim University in Germany. The material used to develop the dryer transparent polyethylene (PE) film with multilayer floor along the drying area to control the heat loss. Both, they run drying experiments in sun and shade in parallel to compare the properties of the final products in term of moisture content, milling recovery and amount of full grain rice. There was reduction in moisture content from 23 to 14 percent within 26 to 52 hours of continuous operation during the rainy season and $16 \%$ to $14 \%$ within $4-26 \mathrm{~h}$ of drying during the dry season. Araujo et al (2019) used designed ground vehicle and called it as Unnamed Ground Vichle (UGV). They used autonomous grain spreader (AGS) powered by electric motor and guided by an electromagnetic field. In addition, they used electronic circuits to obtain and facilitate signals coming from the sensors attached to the grain spreader and to channel the robot on a fixed planned movement. The succeeded to develop a UGV robot and it was used to stir coffee grains during the drying process. Moreover, the UGV was made economically from light material with minimum mechanical interfering to not peel the beans and to ensure quality of the coffee. Additionally, it can be adjusted to work with desired speeds for more homogeneous drying. Such machine can be easily used for drying other grains such as rice, wheat and others. In their study, Missana et al (2020) showed that the solar dryer maintained color and flavor and lowered the original moisture content from $86 \%$ to $10 \%$ for 24 hours compared to 36 hours of drying in open air. The solar impulse efficient solutions are labelled because of their environmental, social and economic impact. However, some of them have the power to radically change people's lives (Lebleu 2020).

For better drying pattern, stirring grain is important operation which represents the critical factor and can the effect the final product quality especially in crop like in rice. In sunny areas, turning the grain is the most important activity to good best quality, where any variation in moisture content within the grain layers will rewet and cause cracking of drier grains and hence bad milling quality (Rice knowledge bank, 2019). For this reason, Dandy et al (2019) developed and manufactured a stirring mechanism for flatbed dryer with additional power not more than or equal to $22.26 \mathrm{HP}(43.5 \mathrm{HP}-21.24$ $\mathrm{HP}$ ). Two electric motors were used to develop the 

for cereals under Egyptian conditions

stirring system, one for transition move and $2^{\text {nd }}$ electric motor plus gearbox to rotate the carrying shaft the direction of move. The stirring device has to motions, translation and rotation with the speed and direction of rotation based on the derived power calculated to run such mechanism, the system was attached to flatbed dryer and was put able to make homogenized drying process throughout the bed. For the cost effective point of view and the complexity of the system, they recommended only electric motors with power not more than 21.24 HP. So, based on above mentioned review studies, the main aim from current study is to provide simple mechanize drying system based on solar modules with considering the mechanical stirring system as essential element to minimize postharvest losses and to increase the quality of rice grains.

\section{MATERIA AND METHODS}

\subsection{Solar dryer}

\subsubsection{Portable drying system (PDS)}

The developed portable drying system (PDS) is natural direct passive solar dryers (natural convection) with simple and cheap construction. Drying chamber consists of best possible insulated frame with inlet and outlet holes and a transparent $4 \mathrm{~mm}$ polycarbonate sheet. In drying process, the available radiation is reflected to the atmosphere while the rest is transmitted inside the drying chamber and absorbed by the rice grain. The overall dimensions and components of PDS is presented in Fig 1. The dryer has dimensions of $5.5 \times 2 \mathrm{~m}^{2}$ (length and width, respectively), and the height is $2.8 \mathrm{~m}$. the performance depends on solar radiation, the relative humidity of the ambient air, and moisture content of the agricultural materials. The bottom (floor) of drying chamber was made with a movable double plastic sheet to enable the loading and unloading of grain with help of mechanical elements.

The solar-heated air is circulated from air heating room through the rice materials to the down chamber by combination of buoyancy forces and air pressure as in Fig 2.

\subsubsection{Air heating room}

Air heating room was constructed similar to a PDS in term of material and constructed to capture heat and make the air is heated enough before entering the drying room. The humid air escapes through an outlets and ventilated through the down chamber of the dryer. The dimension of air heating rom was $2.4 \times 2.4 \times 1.3 \mathrm{~m}$ (length $\mathrm{x}$ width $\mathrm{x}$ height respectively).

\subsubsection{Dryer stirring system}

The stirring system moves transitionally along the long side of the dryer powered by electric motor that runs with solar panel. The transition movement from the steering shaft is done by chains-system. The system will change the direction of movement every 5 meter linear distance of the dryer. With the transition movement, the steering shaft and its connected stirring arms are rotating too. The stirring arms was made from a rectangular $1900 \mathrm{~mm}$ long stainless steel frame (Grade 304 (UNS S30400) of $20 \mathrm{~mm}$ thickness and $70 \mathrm{~mm}$ height and fixed in the steering shaft that moves by chains at both ends (Fig 3). External switch to reverse the rotation direction every $5 \mathrm{~m}$ has been attached by reversing the polarity of the start winding.

\subsection{Power required to stir and to move the stir-} ring system

\subsubsection{Stirring arms and additional loads}

Stainless steel frame size, $\mathrm{V}=\mathrm{L} \times \mathrm{H} \times \mathrm{T}$, where $L$ is the arm length, $W$ is arm height and $T$ is the width. So $V=1900 \times 70 \times 20=266 \mathrm{~cm}^{3}=2.6 \mathrm{~m}^{3}$. Density of used stainless steel is 7.88 grams per cubic centimeter, and thus, stirring arm weight $=7.88$ x $266=2.096 \mathrm{~kg}=9.8 \times 2.096=20.56 \mathrm{kN}$. Grain weight is $17.2 \mathrm{~kg} / \mathrm{m}^{2}\left(0.00172 \mathrm{~kg} / \mathrm{cm}^{2}\right)$ at $3 \mathrm{~cm}$ height of rice grains. These grains load is acting horizontally on the stirring arm with covering area equal to $1900 \mathrm{~mm}$ length as shown in Fig. 3. The area under load is equal to $70 \times 1900=133,000 \mathrm{~mm}^{2}(1330$ $\mathrm{cm}^{2}$ ). So, total load above the shaft is $0.00172 \mathrm{x}$ $1330=0.3 \mathrm{~kg}$. So, both stirring arm weight and grain load is $2.096+0.3=2.4 \mathrm{~kg} \mathrm{~kg} / \mathrm{cm}^{2}$.

\subsubsection{Steering shaft weight and additional loads}

The steering shaft is a hollow shaft with size $\mathrm{V}=$ $\mathrm{pi} / 4 \times \mathrm{M} \times\left(D^{2}-\mathrm{d}^{2}\right)$, where $M$ is the shaft length, $D$ is the outer radius and $d$ is the inner radius. The size is, $\mathrm{V}=\mathrm{pi} / 4 \times \mathrm{M} \times\left(\mathrm{D}^{2}-\mathrm{d}^{2}\right),=3.14 / 4 \times 200 \times(25-16)$ $=1413 \mathrm{~cm}^{3}$. Density of iron is 7.87 grams per cubic centimeter, accordingly, the shaft weight will be equal to $7.87 \times 1413=11.12 \mathrm{~kg}$ or $109 \mathrm{kN}$. For total weight after adding connecting sides to house stirring arm on the steering shaft, total steering shaft 


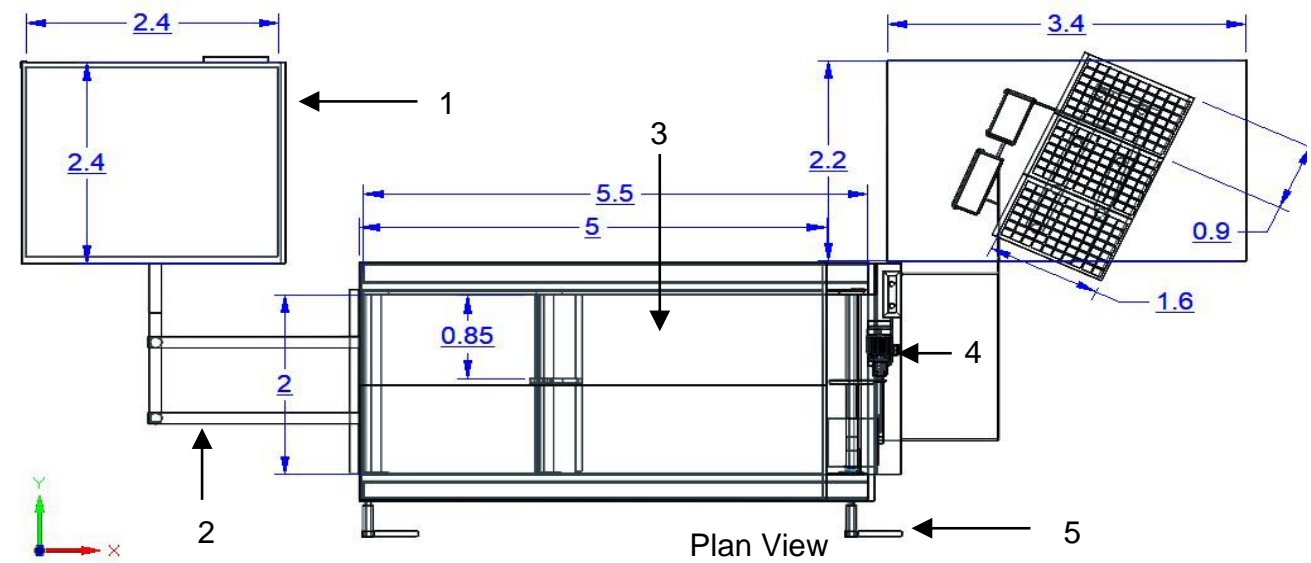

Dim in $m$

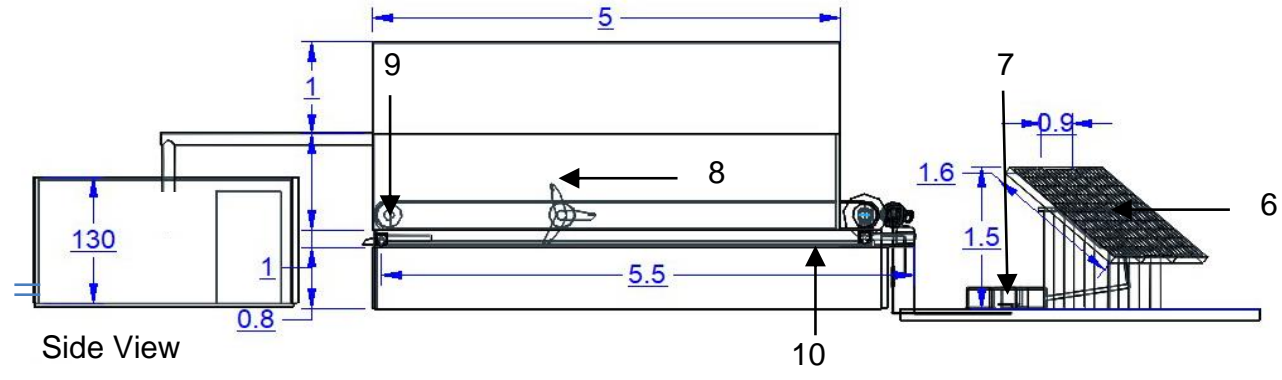

1 air heating room; 2 air inlet tubes; 3 drying chamber 4 electric motor; 5 grain bed mover; 6 solar panel; 7 invertor and batteries; 8 stirring device; 8 inlet/outlet grain gate; 10 movable grain drying bed; down chamber

Fig 1. Solar dryer' overall dimensions and components

Drying air circulation and directions

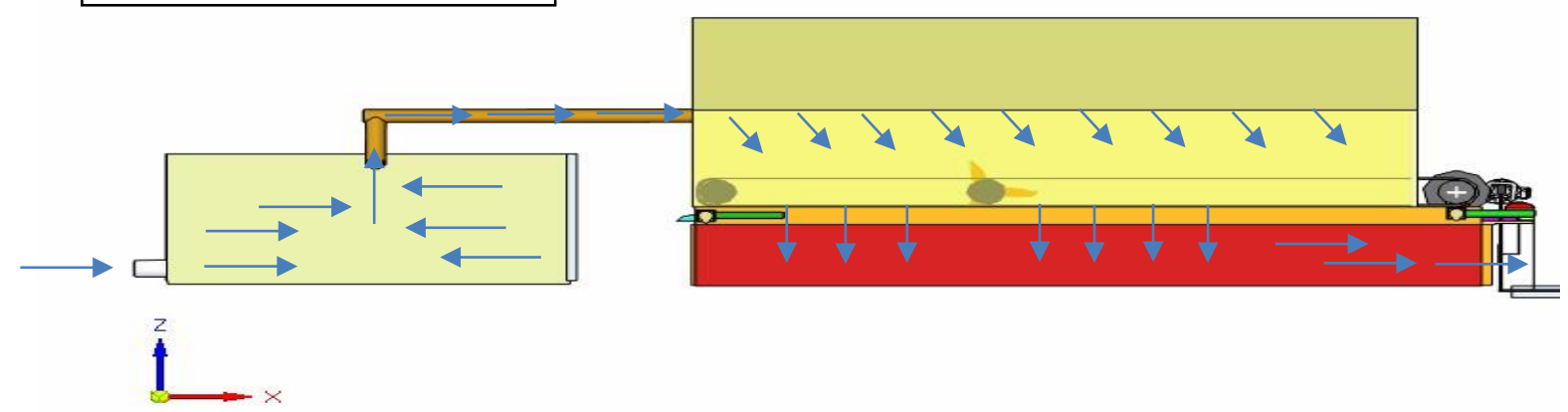

Fig 2. Air circulation in developed PDS 


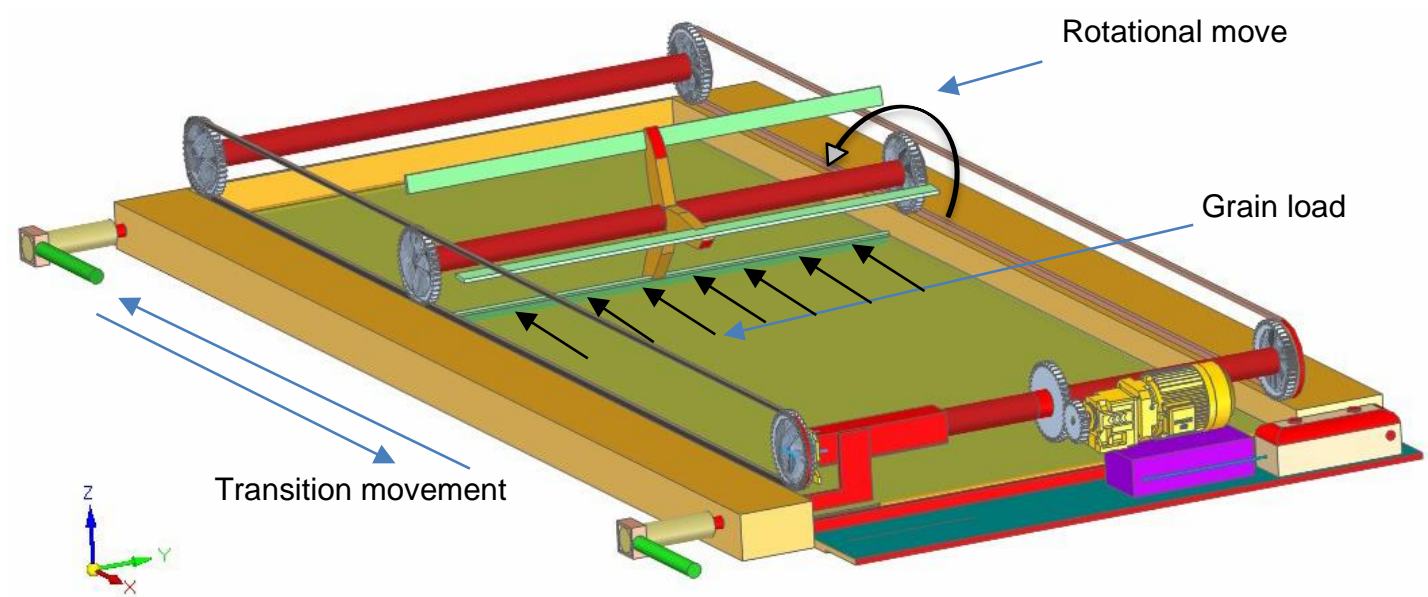

Fig 3. Grain load direction and the two type of stirring system moves

weight will be $11.12+1.2=12.32 \mathrm{~kg}$, and total stirring system weight is $2.4+12.32=14.72 \mathrm{~kg}$ Considering the pulling force with acceleration, the force required to pull the shaft will be under constant speed only at the distant covered by original diameter, the acceleration is happened every $\theta=120^{\circ}$ (the angle between two consecutive stirring arms). With calculating both initial angular velocity $\omega_{0}$, and increased angular velocity $\omega$ as $1.43 \mathrm{rad} / \mathrm{s}$ and 2.86 $\mathrm{rad} / \mathrm{s}$, respectively where $\omega=V / R$ and $R$ is $0.35 \mathrm{~m}$. then the acceleration, $\alpha=\left(\omega-\omega_{0}\right) \Delta t=(2.86-1.43) / 5=$ $0.286 \mathrm{rad} / \mathrm{s}^{2}$ (Fig 4).

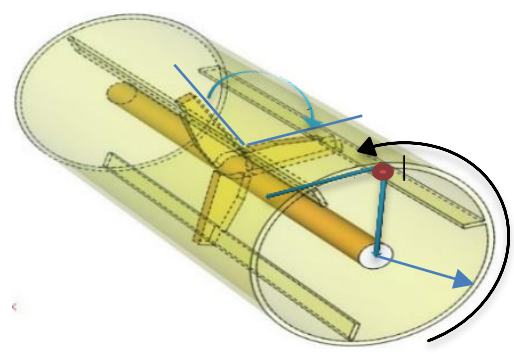

Fig 4. Rotational move and analysis of motion of stirring arms connected to stirring shaft

The equivalent liner acceleration, $\mathrm{a},=\alpha \mathrm{R}=$ $0.286 \times 0.35=0.1 \mathrm{~m} / \mathrm{s}^{2}$. According to applied industrial technology, Coefficients of Friction $\mu$ for steel iron on asbestos, fabric brake material which is behaving like cast iron- grain, $\mu=0.40$. Motion of the body can be determined by using equation of: $F^{*} \mu R$ $=\mathrm{m}^{*} \mathrm{a}$; where $\mathrm{F}$ represents required force; $\mu \mathrm{R}$ represents the force of friction; ma represents the net or resultant force.

$\mathrm{F}=\mathrm{ma}+\mu \mathrm{R}\left(\mathrm{g}=9.81 \mathrm{~m} / \mathrm{s}^{2}\right)=14.72 \times 0.1+(0.4 \mathrm{x}$ $14.72 \times 9.8)=59.17 \mathrm{~kg} \cdot \mathrm{m} / \mathrm{s}^{2}=59.17 \mathrm{~N}$

The force required to accelerate (move the stirring system) is 59.17 Newton's, and the required energy $=59.17 \times 5=295.85 \mathrm{j} / \mathrm{s}=0.4 \mathrm{hp}$. Grain weight at $3 \mathrm{~cm}$ height is $17.2 \mathrm{~kg} / \mathrm{m}^{2}$ and the dryer are is 9.5 $\mathrm{m}^{2}$, so the weight of $161.5 \mathrm{~kg}$ per drying patch.

\subsubsection{Solar panel}

For $1 \mathrm{Hp}$ motor, we are using $300 \mathrm{~W}$ Solar Module. 3 solar panels produce 900 watts. It will be like this after installation. But with time and changes in sun light availability, it is important to ensure enough energy produced to the portable dryer motor. As solar panels produce DC power, you could still use all of your normal 220V AC motor by using an inverter that produces AC Power as its output whenever DC power is provided at its input. Invertor of 3 kva capacity to convert the dc to ac was used with 2 parallel connection of 150 ah batteries to provide required current. Solar panel and its location to the developed dryer is presented in Fig $\mathbf{5}$. 


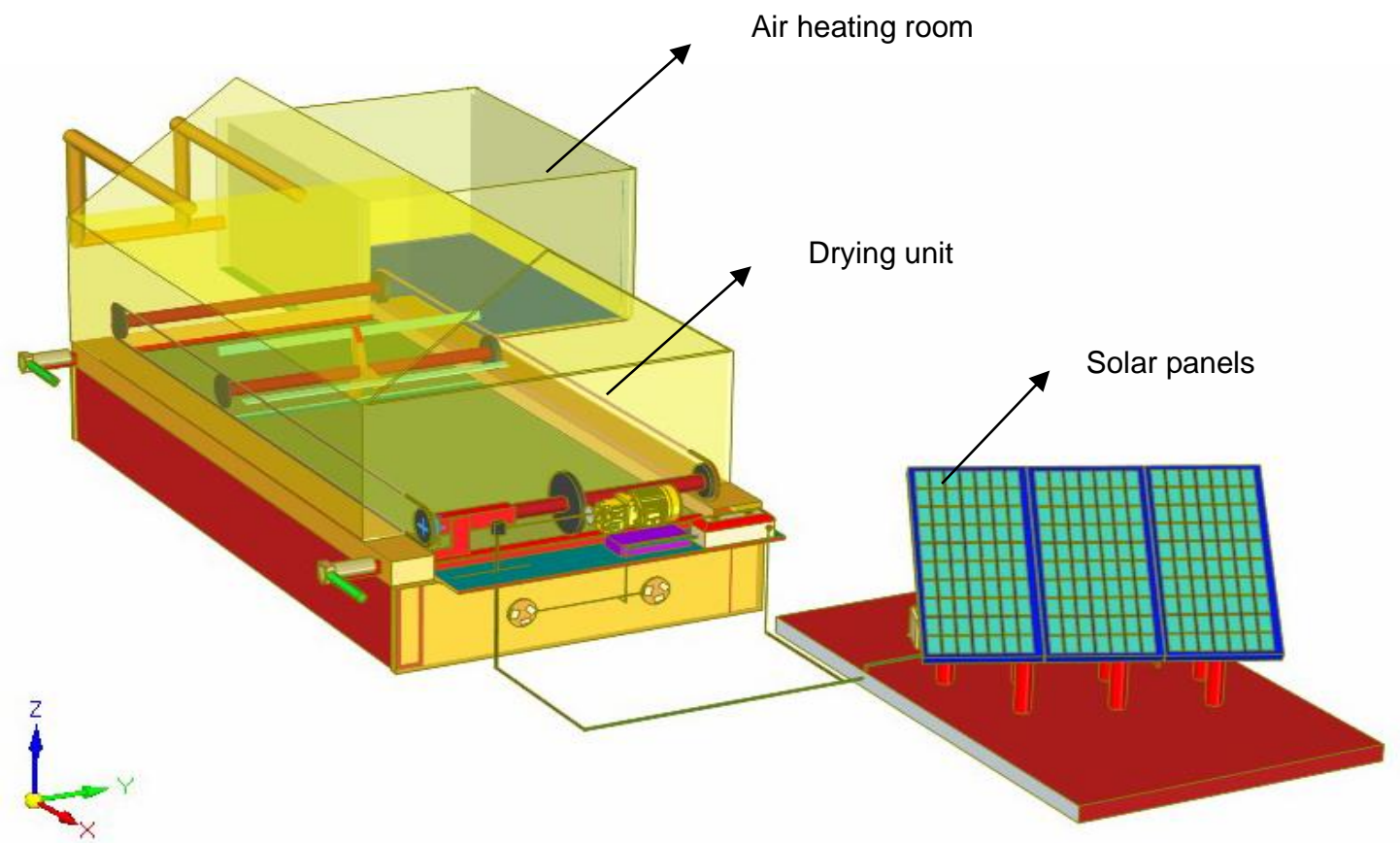

Fig 5. Solar panel and its location to the developed dryer

\subsubsection{Experiments setup}

Experiments were conducted at a private farm in Dakahlia Governorate, Egypt (location: latitude 31.034, longitude 31.3465) in September 2019. The weather data was obtained for 7 days and for the experimental location where all the experiments were conducted (Table 1). Fig 6 shows the monthly average temperature recorded and stored in MarkSim (MarkSim, 2020). The monthly average longwave radiative flux values from Climatology $\mathrm{Re}$ source for SSE-Renewable Energy (NASA Prediction of Worldwide Energy Resources) are presented in Fig 7 (NASA-POWER, 2020). To test the dryer performance against the open air sun drying, harvested SAKHA 101 rice grain was used and with 30 $\mathrm{mm}$ layers. The overall area used to install the dryer was $14 \times 6 \mathrm{~m}^{2}$. The new drying system was evaluated based on the drying time to achieve the target crop moisture content for storage and the difference in crop layers during the drying process. Also, rice milling was conducted after drying to record the milling indicators for both the PDS an open air solar drying. Rice grain samples were gathered from the experimental trials every hour during daytime. Samples of paddy was weighed by an electronic balance of $\pm 0.001 \mathrm{~g}$ accuracy. Moisture content gravimetric method was used at $130{ }^{\circ} \mathrm{C}$ for $16 \mathrm{~h}$ and Moisture content (wet basis) was computed as $\mathrm{MC}=(\mathrm{MI}-$ $\mathrm{MD}$ )/MI X 100; where, MI is the initial mass of the sample before oven-drying, $g$; MD is the final mass of sample, $\mathrm{g}$.

Table 1. Average weather data from 20 to 27 September 2019.

\begin{tabular}{|c|c|c|c|c|}
\hline Parameters & Mean value & Minimum value & $\begin{array}{c}\text { Maximum value } \\
\text { (date) }\end{array}$ & $\begin{array}{c}\text { Number of } \\
\text { observations }\end{array}$ \\
\hline Air temperature $\left({ }^{\circ} \mathrm{C}\right)$ & 25.6 & 18.8 & 30.9 & 63 \\
Atmospheric pressure, $\mathrm{mmHg}$ & 760.6 & 758.7 & 762.3 & 63 \\
Relative humidity (\%) & 63 & 24 & 63 & 63 \\
\hline
\end{tabular}




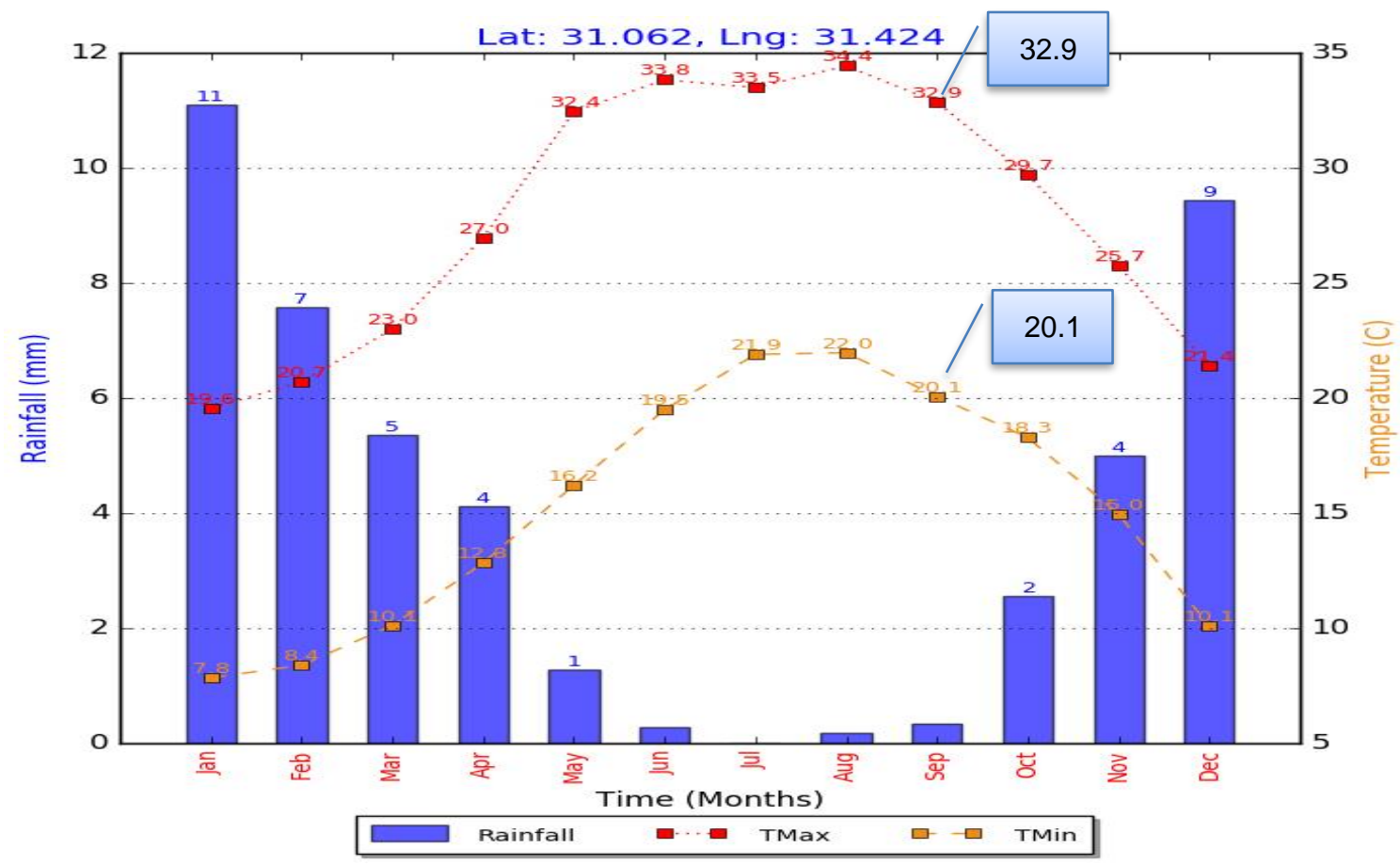

Fig 6. Monthly average temperature recorded in 2019 and stored in MarkSim (MarkSim, 2020)

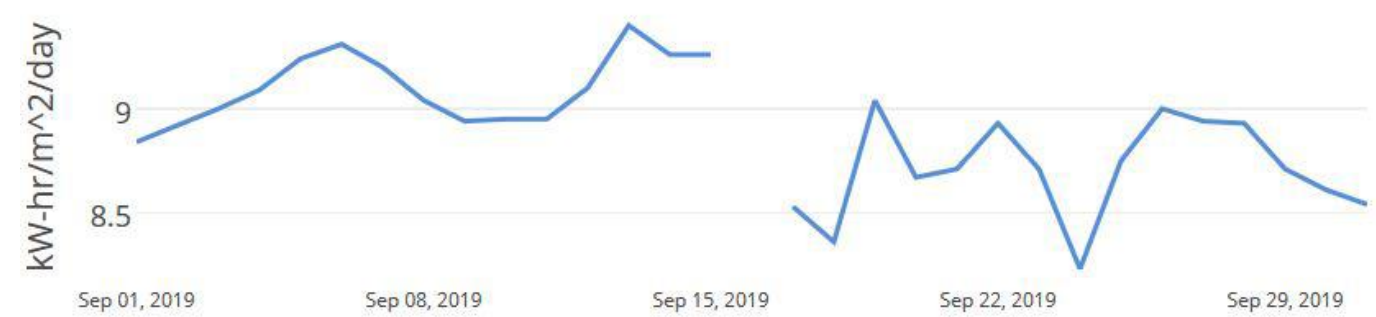

Latitude: 31.0340 Longitude: 31.3465, Time Extent: 09/19/2019 - 09/30/2019, Elevation: 2.89 meters

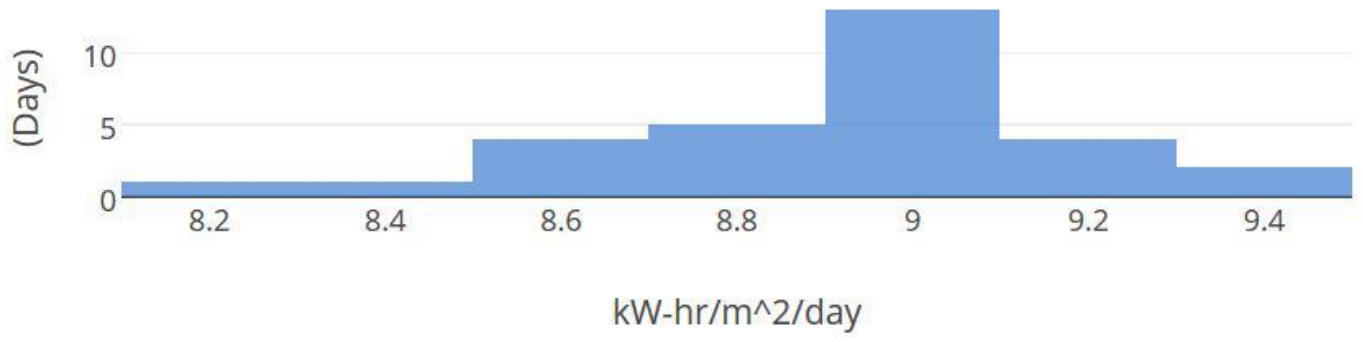

Fig 7. Monthly average longwave radiative flux values during experimental time (NASA-POWER, 2020) 


\section{Results and Discussion}

\subsection{Moisture content behavior}

Average initial MC of the rice was $18 \%$ for all sample before drying. $\mathrm{MC}$ of $12 \%$ was reached in the afternoon and after $10 \mathrm{hr}$ drying with PDS (Fig 8), while in open air sun drying, and in the first day, moisture content reached $14.28 \%$ and the crop needed second day to each the desired $12 \%$ MC for storage, in addition to the increase in MC during night time. The PDS takes less time than conventional sun drying.

\subsection{Temperature in drying layer}

Temperature in upper and bottom drying layers of the grain was recorded and presented in Fig 9 and Fig 10. The results showed the advantages of using PDS for rice drying as there was no significant differences in temperature between upper grain layer and the lower layer. The average difference in temperature was $0.16^{\circ} \mathrm{C}$ for the PDS (Fig 9), while it was $2.77^{\circ} \mathrm{C}$ for the open air sun drying for two different measuring time, $10 \mathrm{am}$ and 2 pm (Fig 10). The less differences in layers' temperature are due to the stirring operation that is undertaken mechanically and on the desired base. The maximum and minimum temperature recorded during the day in the grain inside PDS and in open air sun drying was $46^{\circ} \mathrm{C}$ and $24.5^{\circ} \mathrm{C}$ respectively.

\subsection{Rice milling quality}

Fig 11 Shows the data related to rice milling quality, average head rice percentage with PDS was $86.4 \%$ while it was lower with open air solar drying with $62.83 \%$. Moreover, the recorded average percentages of broken rice were 13.6 and 37.17 $\%$ for PDS and open air solar drying, respectively. The better quality is an indicator that the PDS with its lower temperature differences in rice layers can make dryed rice grain perform better in milling process towards higher head rice and lower broken rice.

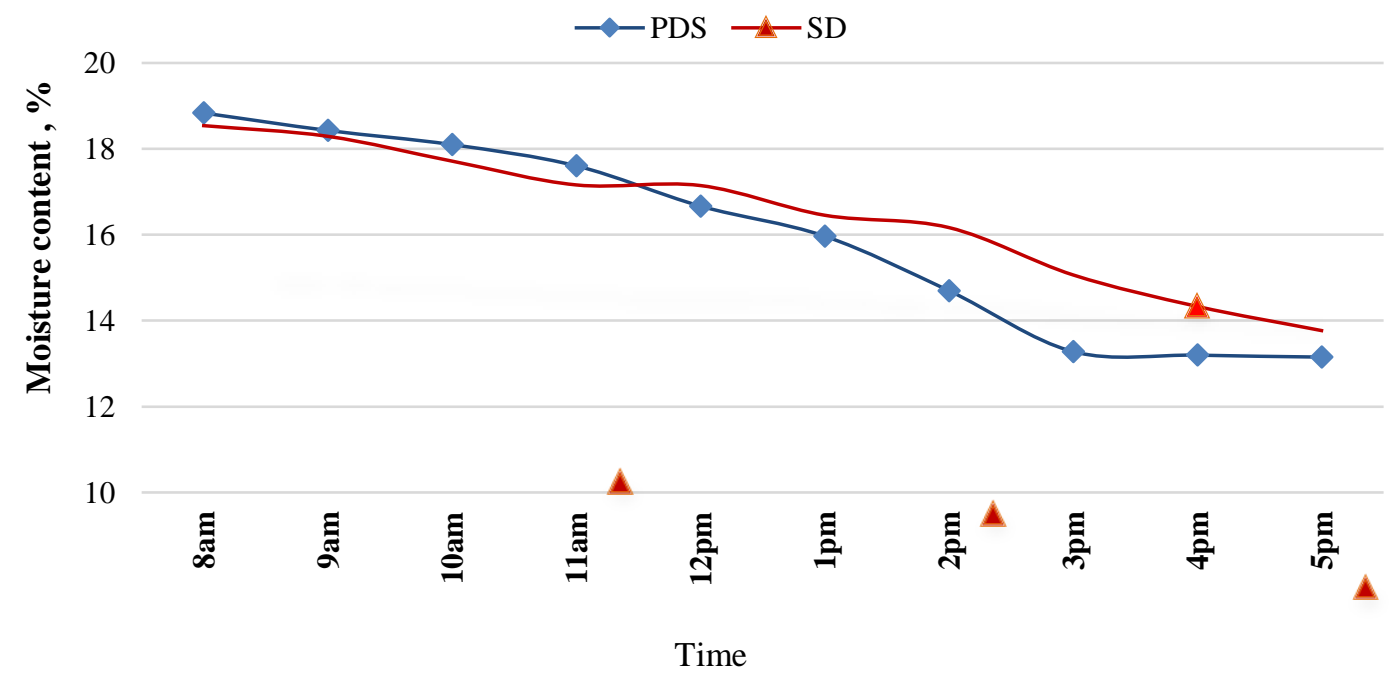

Fig 8. Moisture content of rice in PDS and sun drying 


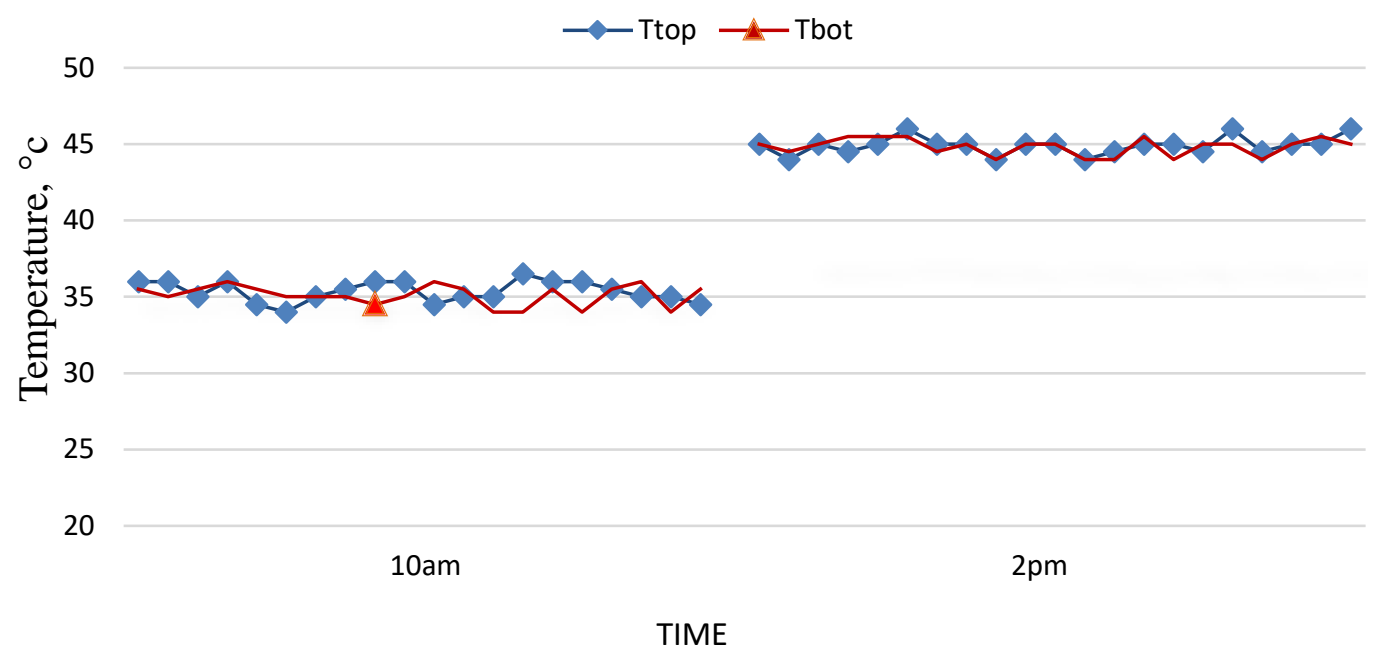

Fig 9. Temperature at the top and bottom layer of rice in PDS

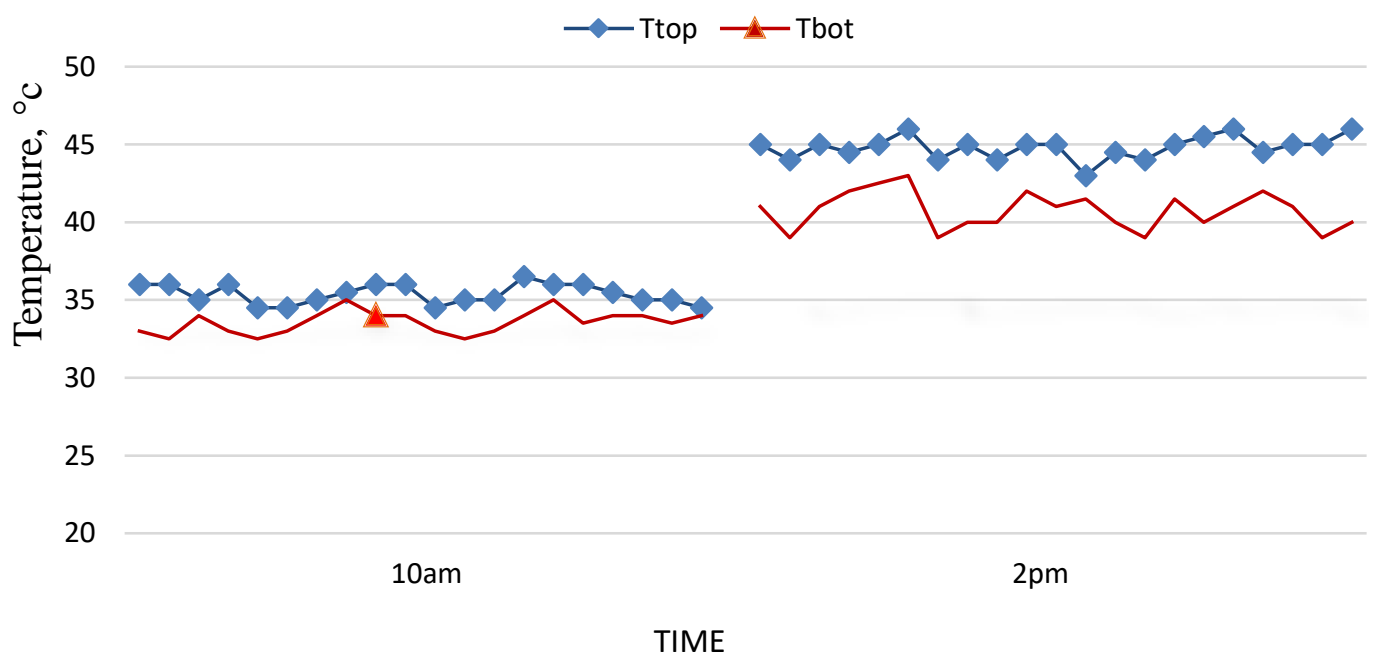

Fig 10. Temperature at the top and bottom layer of rice in open air sun drying 


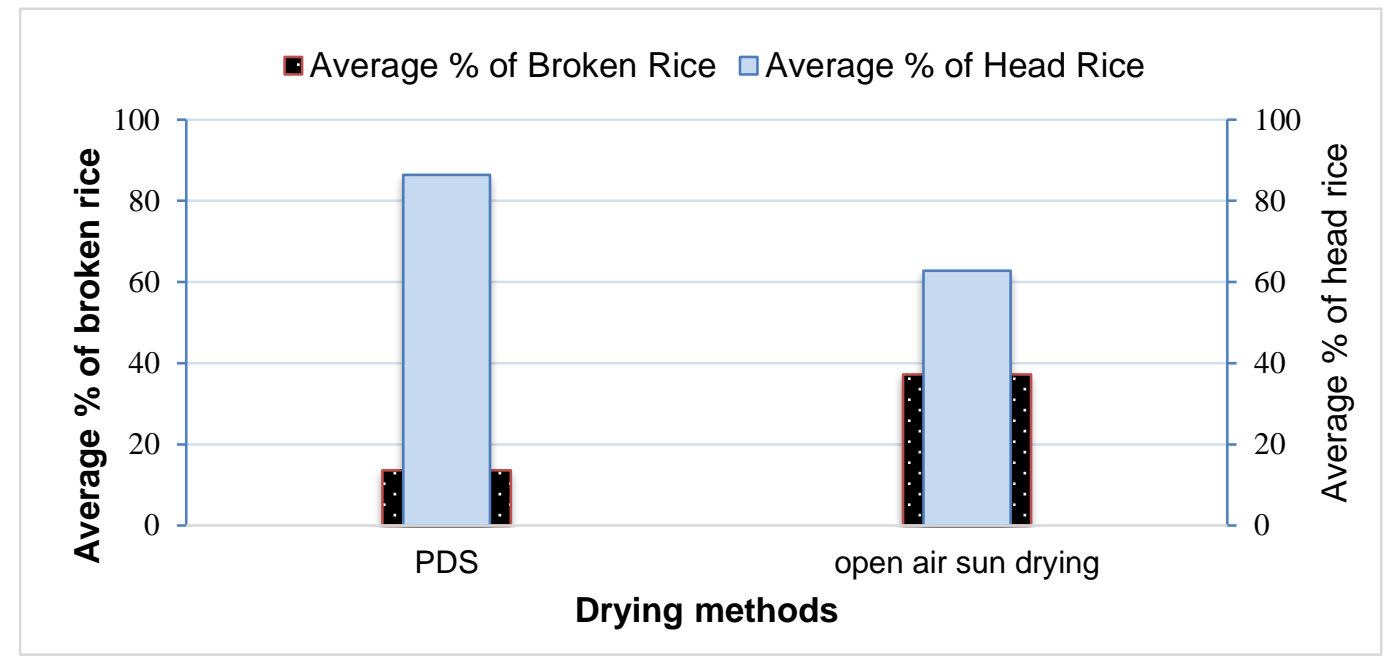

Fig 11. Rice milling quality under two drying methods

\section{Conclusion}

The developed portable drying system (PDS) is perfect option to dry main cereals with $161.5 \mathrm{~kg}$ per drying patch as a capacity for rice. The new dryer is effective in crop protection from insects, rain and birds and no require additional labour for grain mixing and stirring. It can be used with low-cost, works with limited material resources and it need little regular maintenance. The dryer is applicable to many commodities under Egyptian conditions and can dry the rice up to the optimal storage temperature of 12 $\% M C$ in one day. There was no significant differences in top and bottom layer of rice grain which is favourable situation in drying crops. PDS gave better milling quality in term of higher head rice and lower broken rice than the traditional open air solar drying methods.

\section{References}

Araujo, YN; Kalid, RA; Pires, TJR (2019) UGV for the process of Drying Coffee on Patios. Int $J$ Robot Res Appl Autom 1, 18-25. Available at: www.madridge.org/journal-of-robotics-research-applications-and-automation/ijra-1000104.pdf

Aravindh, MA; Sreekumar, A (2014) Solar drying (sustainable way of food processing). By Sharma, AA; Kar, SK (Eds.), Energy Sustainability Through Green Energy. Springer, New Delhi pp. 27-46. https://link.springer.com/chapter/10.1007/978-81322-2337-5 2
Dandy, Z; Sjechlad J Jamari; Widyanto, SA (2019) Auto-Stirring Grains Bed Dryer as an Innovative Efficiency Solution. E3S Web of Conferences 13001, pp. 1-9.

https://doi.org/10.1051/e3sconf/201912513001

Ekechukwu, OV; Norton, B (1999) Review of solarenergy drying systems $2^{\text {nd }}$ (an overview of solar drying technology). Energy Convers Manag 40, 615655.

https://www.tandfonline.com/doi/abs/10.1080/0737 3930902820770

Eltawil, MA; Azam, MM; Alghannam, AO (2018) Energy analysis of hybrid solar tunnel dryer with PV system and solar collector for drying mint (Mentha Viridis). J Clean Prod 181, 352-364. https://www.xmol.com/paper/540972.

Eswara, AR; Ramakrishnarao, M (2013) Solar energy in food processing-A critical appraisal. J Food Sci Technol 50(2), 209-227.

https://link.springer.com/article/10.1007/s13197$\underline{012-0739-3}$

Kumar, M; Sansaniwal, SK; Khatak, P (2016) Progress in Solar Dryers for Drying Various Commodities. Renew Sustain Energy Rev 55, 346. https://econpapers.repec.org/scripts/redir.pf?u=https\%3A\%2F\%2Fdoi.org\%2F $10.1016 \% 2$ 52Fj.rser.2015.10.158;h=repec:eee:rensus:v:55:y: 2016:i:c:p:346-360.

Lebleu, T (2020) Solar Greenhouse Dryer, improving farmers' lives while reducing food waste. 1000 Solutions Articles, Solar Impulse Foundation. Montolivet 19 A, CH-1006 Lausanne, Switzerland. 

for cereals under Egyptian conditions

https://solarimpulse.com/news/solar-greenhousedryer-improving-farmers-lives-while-reducing-foodwaste.

MarkSim (2020) MarkSim web version for IPCC AR5 data (CMIP5) available at: http://gismap.ciat.cgiar.org/MarkSimGCM/\#.

Missana, WP; Park, E; Kivevele, TT (2020) Thermal Performance Analysis of Solar Dryer Integrated with Heat Energy Storage System and a Low-Cost Parabolic Solar Dish Concentrator for Food Preservation. Journal of Energy, 10 pages. https://doi.org/10.1155/2020/9205283.

NASA-POWER, (2020) Monthly average longwave radiative flux values from Climatology Resource for SSE-Renewable Energy. NASA Prediction of Worldwide Energy Resources. POWER Project Team, NASA Official.

https://power.larc.nasa.gov/data-access-viewer/.

Piacentini, RD; Mujumdar, AS (2009) Climate change and the drying of agricultural products. Dry Tech 27, 629-635.

https://www.tandfonline.com/doi/abs/10.1080/0737 3930902820770

Purohit, P; Kumar, A; Kandpal, TC (2006) Solar drying vs. open sun drying: a framework for financial evaluation. Sol Energy 80, 1568-1579. https://www.sciencedirect.com/science/article/abs/pii/S0038092X06000302
Renewable Energy Policy REN21, (2017) Global Status Report. Renewable Energy Policy Network for the $21^{\text {st }}$ Century (REN21), Paris, France. http://www.ren21.net/wp-content/uploads/2017/06/17-8399 GSR 2017 Full Report 0621 Opt.pdf

Rice Knowledge Bank, (2019) Fact sheets of postharvest management in sun drying. IRRI. Philippines. Available at: http://www.knowledgebank.irri.org/training/fact-sheets/postharvest-management/drying-fact-sheet-category/sun-dryingfact-sheet?layout=item.

Salvatierra-Rojas, A; Nagle, M; Gummert, M; de Bruin, T; Müller, J (2017) Development of an inflatable solar dryer for improved postharvest handling of paddy rice in humid climates. Int JR Agric Biol Eng 10, 269-282. http://www.stiftung-fiatpanis.de/images/PF/PF2011 16a.pdf.

Tiwari, S; Tiwari, GN; Al-Helal, IM (2016) Development and Recent Trends in Greenhouse Dryer: Renew Sustain Energy Rev 65, 104. https://doi.org/10.1016/j.rser.2016.07.070.

WHO (2005) Health Effects of Transport-Related Air Pollution. World Health Organization (WHO) Regional Office for Europe, Copenhagen, Denmark accessed. $\quad \underline{w w w . e u r o . w h o . i n t / ~ d a t a / a s-~}$ sets/pdf file/0006/74715/E86650.pdf. 


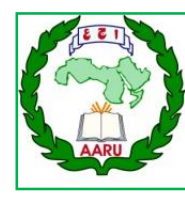

مجلة اتحاد الجامعات العربية للعلوم الزراعية، جامعة عين شمس، القاهرة، مصر

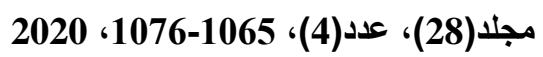

\author{
أحمد محمد الثيخة"1 - رشاد عزيز حجازي2" \\ 1- قسم الهندسة الزراعية - كلية الزراعة - جامعة دمياط - محافظة دمياط - ص.ب. 34517 - مصر

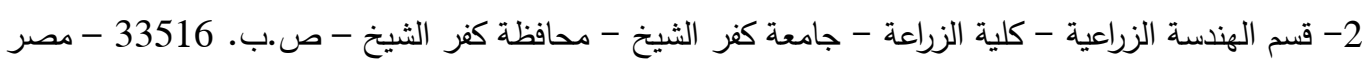

*Corresponding author: rashad.hegazy@agr.kfs.edu.eg

Received 19 September, 2020

Accepted 21 October, 2020

الاعتبار وقت التجفيف ودرجة حرارة التجفيف كاساس التساس

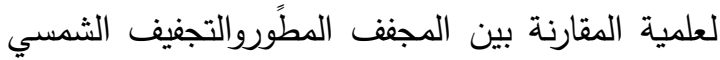

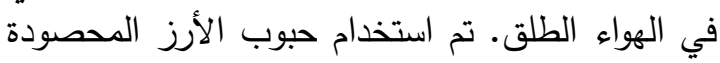

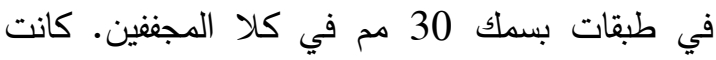
المساحة الإجمالية المستخدمة لتركيب المجفف 14 × 14 كات

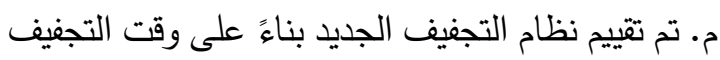

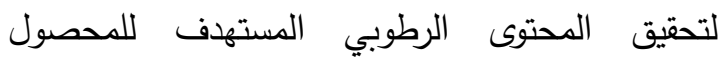

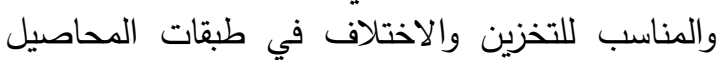

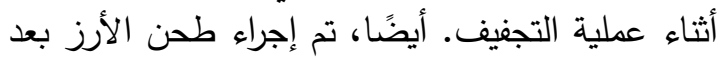

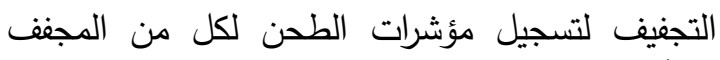

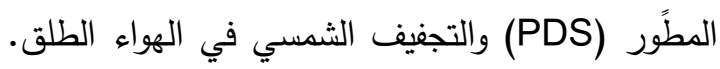
كان متوسط الفرق في درجة الحرارة 0.16 درجة مئوية الفئية

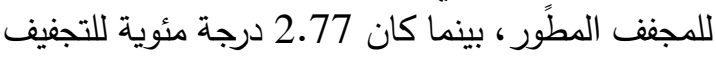

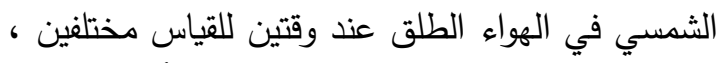

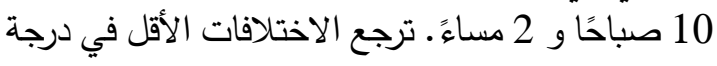
حرارة الطبقات إلى عملية التحريك التي تتم ميكانيكيًا.

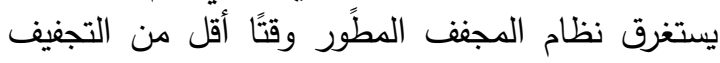

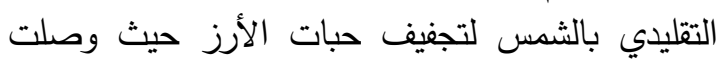
حبات الأرز إلى 12٪ محتوي رطوبي بعد 10 ساعات

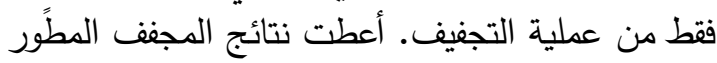
جودة طحن أفضل ، من حيث الحبات الكاملة بدون كسر، من طريقة التجفيف الثمسي التقليدية في

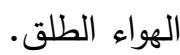

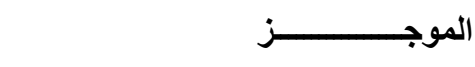

الهدف الرئيسي من هذه الدراسة هو استخدام الطاقة

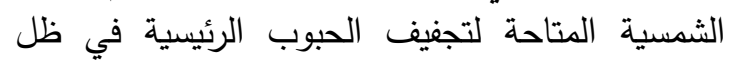

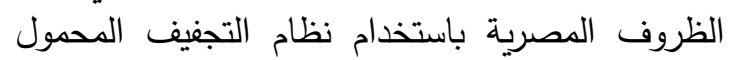

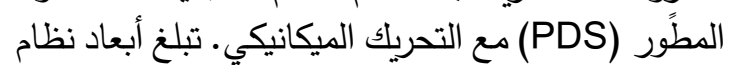

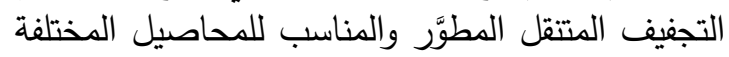

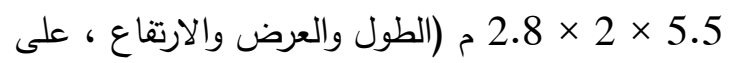
التوالي)، والارتفاع 2.8 × 2.8 م. كانت أبعاد غرفة تسخين

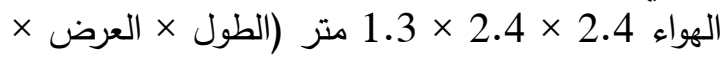

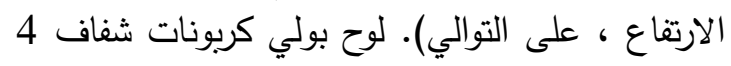

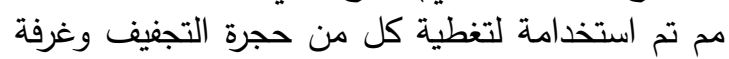
التسخين. تم إرفاق نظام تحريك انتقالي يعمل بمحرك دئك

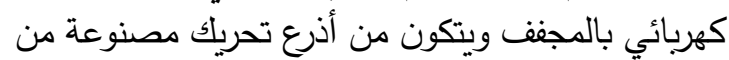
ألواح مستطيلة من الفولاذ المقاوم للصدئ أبطون 1900

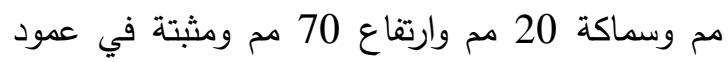
التوجيه الذي يتحرك بواسطة سلاسل حركة في كلاع

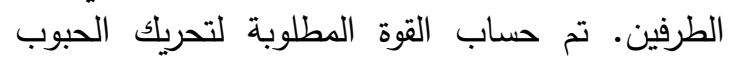
والتحريك الدوراني وتحليل الحركة لتحديد قدرة المحرك الحصانيه المناسبه لاستخدامه. ثلاث وتلئ وحدات شمسية

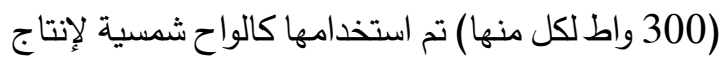
900 واط (مع الأخذ في الاعتبار كفاءة الألواح الشمسية) وذللك لتتشغيل المحرك الكهربائي. تم الأخذ في الأح الأح 